\title{
INFLUENCE OF HYSTEROSCOPIC METROPLASTY ON REPRODUCTIVE OUTCOME IN PATIENTS WITH INFERTILITY AND RECURRENT PREGNANCY LOSS
}

\section{Gligor Tofoski, Vesna Antovska}

PHI University Clinic of Gynaecology and Obstetrics, Medical Faculty, St. Cyril and Methodius University, Skopje, Republic of Macedonia

Corresponding Author: Tofoski Gligor, University Clinic of Gynaecology and Obstetrics, Vodnjanska 17, 1000 Skopje, R. Macedonia, E-mail: gtofoski@yahoo.com

\begin{abstract}
Introduction: Patients with congenital uterine anomalies (CUA) have decreased reproductive potential and an unfavourable reproductive outcome compared to the population with normal uterine cavity. Patients with untreated CUA have a higher abortion rate, higher foetal loss rate and decreased live birth rate. Hysteroscopic metroplasty is a standard, safe and minimally invasive method for the treatment of correctible types of congenital uterine anomalies.

The aim of the study was to analyse the reproductive outcome in certain groups of patients with CUA and infertility, before and after hysteroscopic metroplasty.

Material and methods: We analyzed 115 patients on whom 129 hysteroscopic metroplasty interventions were performed at the University Clinic of Obstetrics and Gynaecology in Skopje over a oneyear period, between 01.01.2011 and 31.12.2011. Patients and their reproductive outcome were monitored over a two-year period and the same group served as a control group, taking into account their previous reproductive history before and after metroplasty. Statistical analysis was performed using the Chi-square test and $\mathrm{p}<0.05$ was considered to be statistically significant.

Results: The most common CUA were types $5 \mathrm{~b}$ and 6 , represented by $83.3 \%$. In a follow-up period of two years, there were 55 patients with previous foetal loss treated by hysteroscopic metroplasty, and 31 of them had pregnancies. There was a statistically significant decrease of abortion rate from $88.5 \%$ to $19.3 \%$, and a significant increase in term delivery rate from $2.3 \%$ to $71 \%$.

Conclusion: Hysteroscopic metroplasty significantly improves the reproductive outcome in patients with previous foetal loss.
\end{abstract}

Key words: hysteroscopy, reproduction, infertility, pregnancy.

\section{Introduction}

The influence of congenital uterine anomalies (CUA) on the reproductive outcome has been a research question for a long period of time. Congenital anomalies of the female reproductive tract (Mullerian anomalies) represent a heterogeneous group of malformations of the genital tract, which can involve uterus, cervix, vagina and Fallopian tubes. The majority of reproductive tract anomalies can seriously influence the reproductive and obstetric health of women depending on the specificity of the anomaly.
Newly published literature showed that the prevalence of congenital uterine anomalies is around $1-10 \%$ in an unselected population of women, $2-8 \%$ in the group of infertile women, and $5-30 \%$ in women with a previous miscarriage (early and late abortions, early preterm delivery) [1-3]. Prevalence of the anomalies differs depending on the method used for detection and diagnosis, with variable test performance, and the use of different classification systems to define the congenital uterine anomaly. Septum of the uterus is the most frequent 
congenital anomaly of the genital tract with an incidence of $2-3 \%$ in the general population [4].

Congenital uterine anomalies consist of different groups of malformations of the Mullerian ducts, as a result of arrested embryological development, abnormal development or incomplete fusion of the paramesonephric ducts [5].

The etiology of the congenital anomalies of the female reproductive tract is still not adequately explained. In most women with Mullerian anomalies, karyotype is normal (92\%). There are many hypotheses and theories implicating genetic factors, environmental and phar- macological influences, but probably polygenic or multifactorial mechanisms are present [6].

Several classifications have been made in order to optimize the diagnosis and treatment of these anomalies, but the one adopted by the American Fertility Society (AFS) in 1988 [7] has been most beneficial in clinical practice. It classifies the anomalies of the female reproductive tract depending on the degree of failure of normal development, in groups of similar clinical manifestations, treatment and prognosis for their reproductive outcome.

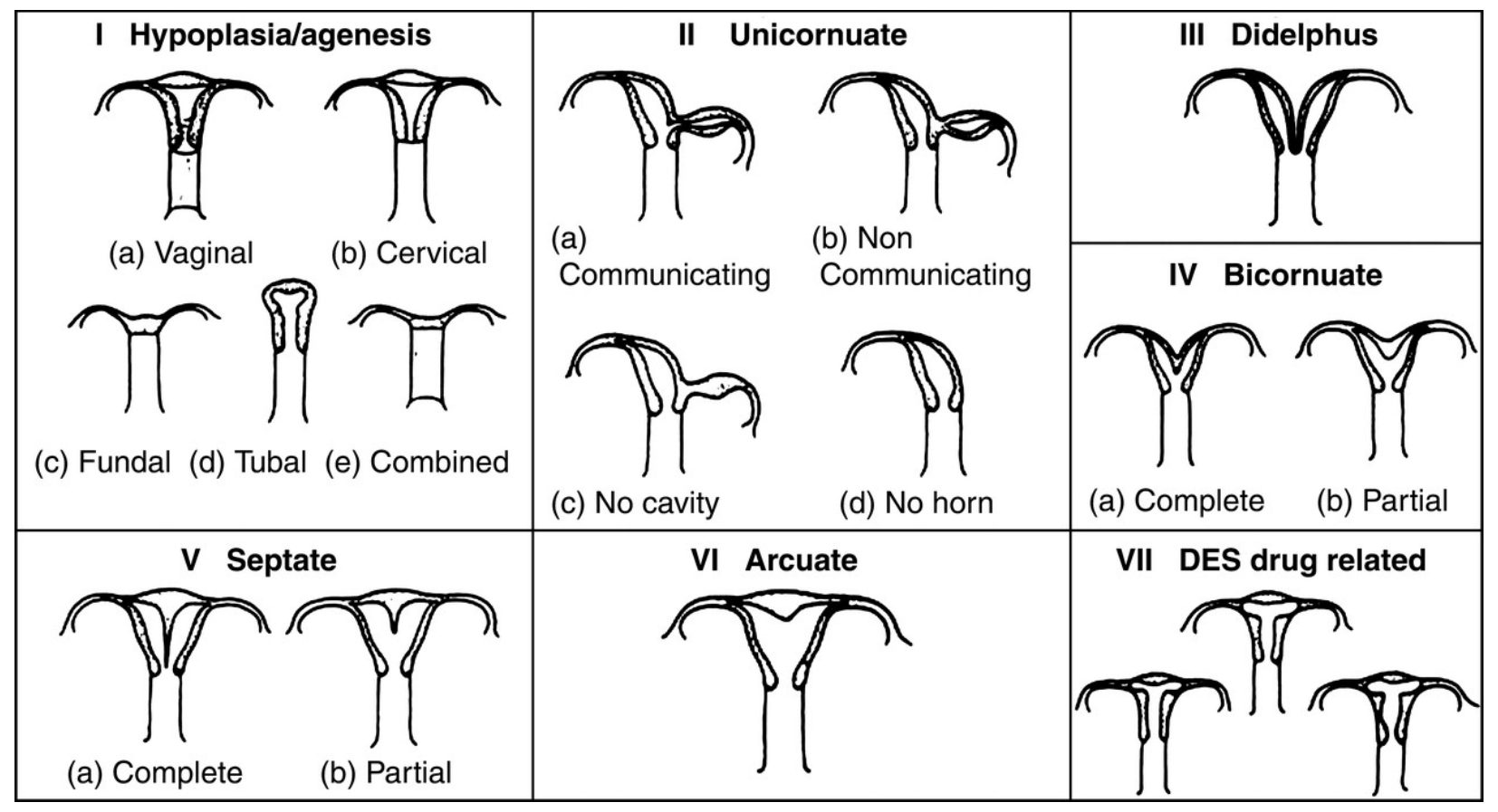

Figure 1 - Schematic presentation of AFS classification

Detection and diagnosis of the CUA can be considered optimal using a combination of hysteroscopy, laparoscopy, 3D ultrasound or MRI and sonohysterosalpingography [8]. In most medical centres hysteroscopy and laparoscopy is a standard, safe and minimally invasive method for precise detection, classification and treatment of uterine malformations [9-13].

Abnormality of the uterine cavity is considered to be one of the factors which influence the reproductive outcome of these patients. A good surgical correction by metroplasty provides an anatomically normal uterine cavity, but does not unfailingly result in a favourable reproductive outcome since uterine vascularization is probably involved in the uterine function. The theory which is nowadays widely accepted states that septum consists of fibroelastic tissue with inadequate vascularization and a changed ratio between blood vessels of the endometrium and myometrium, presenting negative effects on decidualisation and placentation [14].

Transcervical treatment with hysteroscopy, since its innovation, has been the most efficient and easy method of surgical correction, allowing the operator to diagnose and treat the CUA. Hysteroscopic metroplasty has all the benefits of a good operative treatment: decreesed intra- and post-operative morbidity, shorttime intervention, fewer analgesic requirements, a shorter hospital stay, a shorter interval to conception and the possibility of a vaginal delivery. 

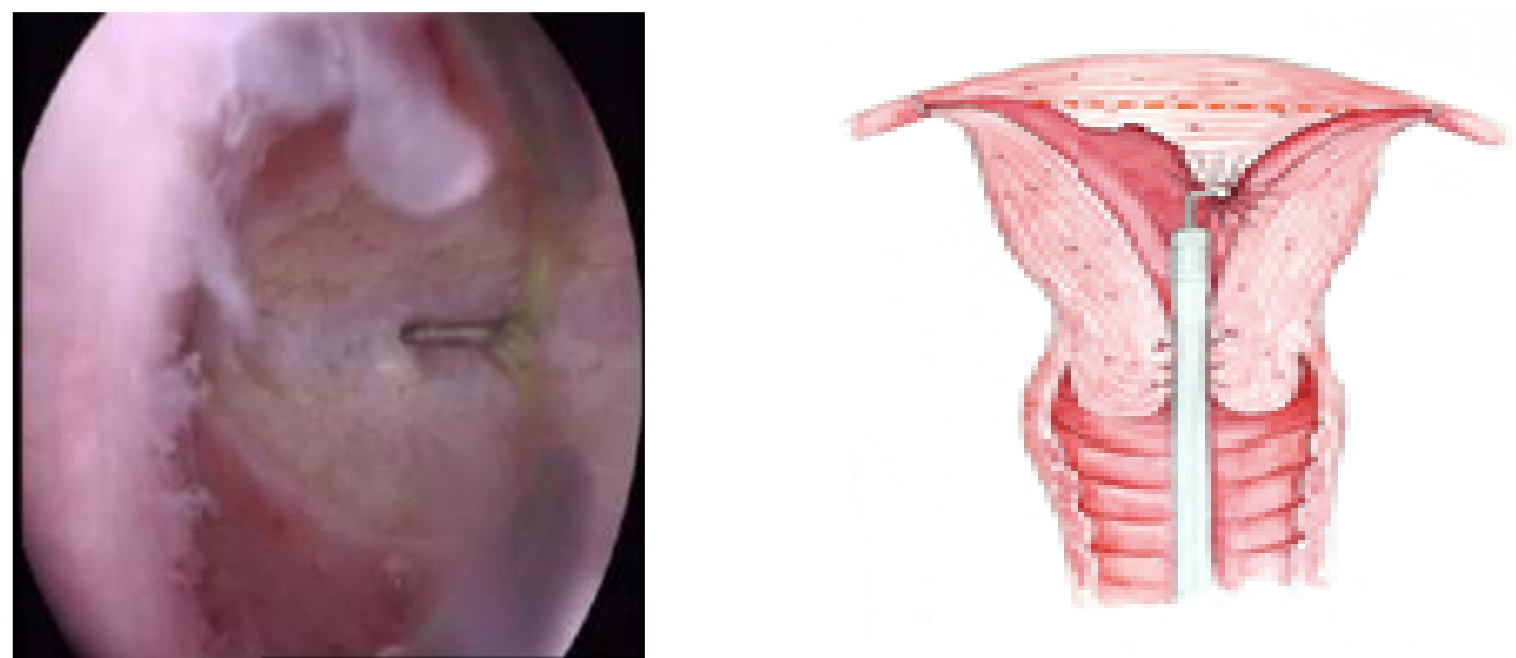

Figure 2 - Hysteroscopic metroplasty in uterus septus

Most research findings have revealed that the majority of uterine malformations $(>55 \%)$ are presented with septate and arcuate uterus (type s5 and 6 according to AFS classification), which can be effectively treated by means of operative hysteroscopy $[14,15]$. Partial reconstruction of the uterine cavity by hysteroscopy is possible in some cases of partial bicornuate uterus (type 4b). Hysteroscopic metroplasty obtains a normal uterine cavity, but also resolves normal uterine function, by providing a normal reproductive outcome in these patients [16-18].

\section{Spontaneous abortion (foetal loss)}

Foetal loss (unsuccessful pregnancy) can be manifested in any period of pregnancy, starting even before implantation. The largest number (around 2/3) of foetal losses after implanttation cannot be clinically detected, only by means of HCG testing, known as biochemical pregnancy [19-21].

The clinical rate of abortion diagnosis is $10-12 \%$, which is well documented in a large number of retrospective and prospective studies. Foetal death occurs before the presence of clinical signs, and only $2-3 \%$ of viable pregnancies are lost after 8 gestational week of pregnancy, usually in the following two months [22-24].

Abortion causes can be of idiopathic, genetic, anatomical, autoimmune, endocrine and infective origin [25]. The most frequent causes are considered chromosomal anomalies, infective agents, the presence of uterine anomalies or other uterine pathology, antiphospholipid syndrome, uncontrolled diabetes etc.

According to the definitions for infertility and recurrent pregnancy loss by the American Society for Reproductive Medicine, the following table was made:

Table 1

Terms Used to Describe Pregnancy Loss

\begin{tabular}{|c|c|}
\hline Term & Definition \\
\hline $\begin{array}{l}\text { Chemical pregnancy } \\
\text { loss }\end{array}$ & Loss of a biochemically evident pregnancy \\
\hline Early pregnancy loss & $\begin{array}{l}\text { Abortion of the first trimester, loss of a histologically recognized pregnancy, or a loss } \\
\text { based on ultrasonographic findings }\end{array}$ \\
\hline $\mathrm{SAB}$ & Pregnancy loss before 20 weeks' gestation, as based on last menstrual period \\
\hline $\begin{array}{l}\text { Habitual or recurrent } \\
\text { abortion }\end{array}$ & 2 or more consecutive SABs* \\
\hline Stillbirth & Pregnancy loss after 20 weeks' gestation (Neonatal loss is the death of a liveborn fetus.) \\
\hline
\end{tabular}


Even after one pregnancy loss, the risk of failure of the following pregnancy has been increased by $16-25 \%$, and after a second and third foetal pregnancy loss (unsuccessful pregnancy), the risk of a following foetal loss has been increasing up to $40 \%[26,27]$.

Table 2

Calculated risk of repetitive pregnancy loss for counselling patients with previous spontaneous abortions [26]

\begin{tabular}{|l|c|c|}
\hline & Previous abortion & Risk (\%) \\
\hline $\begin{array}{l}\text { Patints with previous } \\
\text { livebirth }\end{array}$ & 0 & $5-10$ \\
\hline & 1 & $20-25$ \\
\hline & 2 & 25 \\
\hline & 3 & 30 \\
\hline $\begin{array}{l}\text { Patients without } \\
\text { previous livebirth }\end{array}$ & 3 & 30 \\
\hline
\end{tabular}

This is the reason patients with a previous history of spontaneous abortion should undergo all the examinations searching for preventable causes for a prevention of a future pregnancy loss. It should comprise taking a good medical history, a thorough medical examination, patient counselling and laboratory tests. An ultrasound scan is mandatory to search for the existence of uterine pathology (anomalies, polyp, myoma), and microbiological swabs for infective agents. Analysis of TSH and glycaemia should also be done. In cases of recurrent foetal loss tests should be done for antiphospholipid antibodies, karyotype, and HLA status.

\section{Influence on reproductive outcome}

The presence of uterine malformations can have a further negative impact on the reproductive outcome, by additionally increasing the rate of abortions, preterm deliveries, and obstetric complications. Patients with uterine malformations have decreased reproductive potential and an unfavourable reproductive outcome, starting even from the first pregnancy. Overall term pregnancy rate in patients with untreated uterine malformations is around $50 \%$. Patients with uterus didelphus and unicornuate uterus have a term delivery rate of $\sim 45 \%$, and pregnancies with untreated septate and bicornuate uterus of $\sim 40 \%$. In patients with arcuate uterus the reproductive outcome is slightly better, with a term delivery rate of $\sim 65 \%$ [12].

The aim of this study was to analyse the influence of hysteroscopic metroplasty of congenital uterine anomalies in patients with infertility and recurrent pregnancy loss on their consecutive reproductive outcome.

\section{Material and method}

We analysed 115 patients on whom 129 hysteroscopic metroplasty interventions (HM) were performed at the University Clinic of Obstetrics and Gynaecology in Skopje over a oneyear period, between 01.01.2011 and 31.12.2011. Inclusion criterion for the study was diagnosis of uterine malformation of correctible types ( $4 b, 5 a, 5 b$ and 6$)$, according to the AFS classification, and exclusion criteria were the existence of other intrauterine pathologies (submucous myoma, polyp, etc.).

The inclusion criterion was met by 113 patients, who underwent 127 interventions. Patients were divided into three groups: patients with recurrent pregnancy loss (RPL), patients with secondary infertility and previous pregnancy loss, and patients with primary infertility. Patients and their reproductive outcome were monitored during a two-year period and the same group served as a control group for themselves, taking into account their previous reproductive history before and after metroplasty. Hysteroscopic metroplasty was performed following previously signed informed consent by the patient.

The intervention was made with endoscopic equipment (Olympus and Storz types), using a rigid hysteroscope of $5.5 \mathrm{~mm}$ and a resectoscope of 8 and $9 \mathrm{~mm}$, under general anaesthesia and in sterile conditions. Monopolar and bipolar current was used for the resection, with 50-70W strength and a special electrode (eza needle) of $4 \mathrm{~mm}$ length. A mixed solution of Ispirol ${ }^{\circledR}$ (solution of $2.7 \%$ sorbitol and $0.54 \%$ manitol) or $\mathrm{NaCl} 0.9 \%$ solution, sterile and apyrogenic, served as a distension media.

The procedure starts with the patient placed in a lithotomic position, after previous disinfection of the operative field and vagina. Then the cervix is pulled forward with a tenaculum and dilatation is done using Hegar dilatators; the hysteroscope is placed transcervi- 
cally into the uterine cavity. After visualization of both tubal ostia, resection of the septum starts in the midline between the anterior and posterior uterine wall and continues cranially towards the end point. The end point is the moment when the following has been achieved: the hysteroscope can move freely from one to the other ostium without obstruction, when both ostia are easily visualized from the upper part of the cavity or when more intensive bleeding starts from the place of the resection as a sign of proximity to the junction between the septum and the myometrium. When a bigger septum is present or uncertainty is present about achieving the end point of the resection, the intervention is interrupted and the patient is assigned for a control ultrasound and eventual re-resection.

In order to make a correct diagnosis of the uterine malformation or cause of infertility, in several patients laparoscopy was done. During the procedure for hysteroscopic metroplasty laparoscopic control is not necessarily needed.
The following variables associated with the reproductive outcome were monitored in our group of patients: pregnancy rate, abortion rate, preterm delivery rate and term delivery rate.

Data were analysed using the SPSS program for Windows, version 11.0. Statistical analysis was done using the Chi-square test and a p-value of 0.05 was considered to be statistictically significant.

\section{Results}

The 113 patients were divided into three groups: the group with recurrent pregnancy loss consisted of 22 patients (19.5\%); the group with secondary infertility consisted of 33 patients $(29.1 \%)$ and the group with primary infertility consisted of 58 patients $(51.4 \%)$. Twenty-seven interventions $(21 \%)$ were done in the group of patients with RPL, 35 (28\%) in the secondary infertility group and $65(51 \%)$ interventions in the primary infertility group.

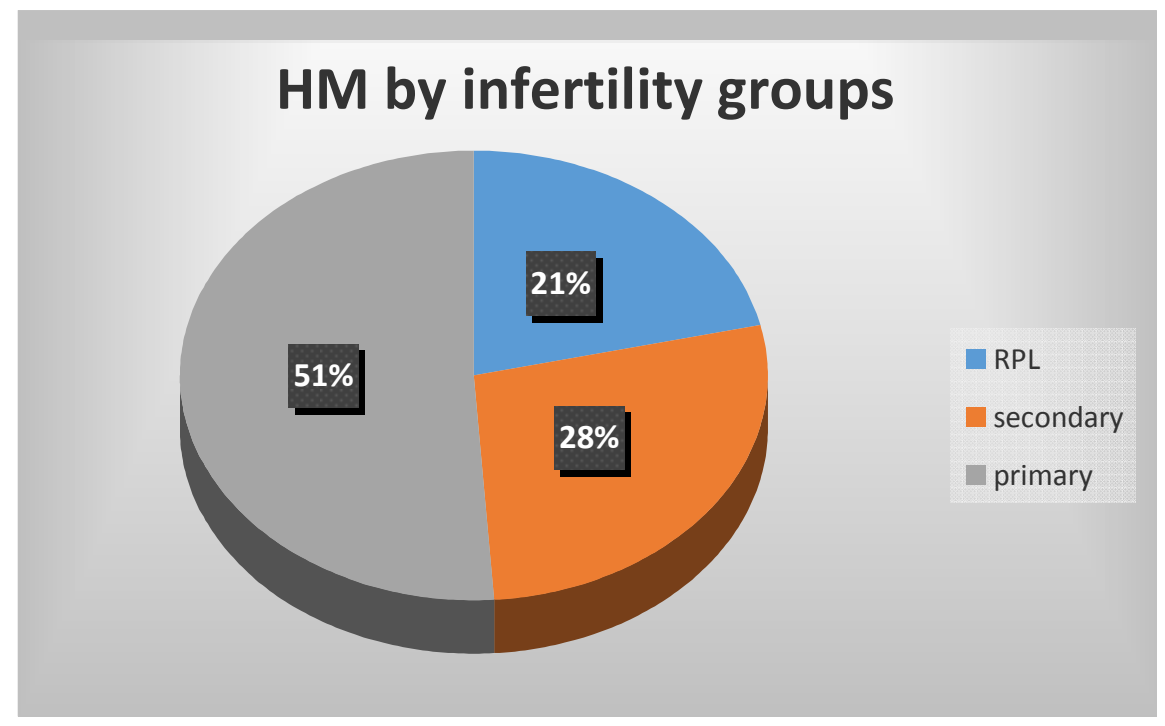

Figure 3 - Graphic presentation of hysteroscopic metroplasty by infertility groups

Comparing the number of diagnosed anomalies - the largest number of $69(61.1 \%)$ hysteroscopic metroplasties were done in the group of patients with arcuate uterus (type 6), followed by the group of patients with partial septate uterus (type $5 b)-24$ cases $(21.2 \%)$ and the group of patients with partial bicornuate uterus (type $4 b)-13$ cases $(11.5 \%)$. The least frequ- ent anomaly was complete septate uterus (type $5 a)$ in 7 patients $(6.2 \%)$.

As represented in most of the published literature, in all of the infertility groups we analysed the most frequent congenital uterine anomalies were types $5 \mathrm{~b}$ and 6 - partial septate uterus and arcuate uterus, represented by $83.3 \%$. 
Table 3

Frequency of certain types of CUA by groups

\begin{tabular}{|c|c|c|c|c|}
\hline $\begin{array}{c}\text { Type of } \\
\text { CUA }\end{array}$ & $\begin{array}{c}\text { RPL } \\
(\%)\end{array}$ & $\begin{array}{c}\text { Secondary infertility } \\
(\%)\end{array}$ & $\begin{array}{c}\text { Primary infertility } \\
(\%)\end{array}$ & $\begin{array}{c}\text { Total } \\
(\%)\end{array}$ \\
\hline $4 \mathrm{~b}$ & 0 & $6(18.2 \%)$ & $7(12.1 \%)$ & $13(11.5 \%)$ \\
\hline $5 \mathrm{a}$ & 0 & $2(6.1 \%)$ & $5(8.6 \%)$ & $7(6.2 \%)$ \\
\hline $5 \mathrm{~b}$ & $7(31.8 \%)$ & $6(18.2 \%)$ & $11(19.0 \%)$ & $24(21.2 \%)$ \\
\hline 6 & $15(68.2 \%)$ & $19(57.5 \%)$ & $35(60.3 \%)$ & $69(61,1 \%)$ \\
\hline Total & $22(100 \%)$ & $33(100 \%)$ & $58(100 \%)$ & $113(100 \%)$ \\
\hline
\end{tabular}

Table 4

Types of CUA and need for re-intervention

\begin{tabular}{|c|c|c|c|c|}
\hline $\begin{array}{c}\text { Type } \\
\text { of } \\
\text { CUA }\end{array}$ & $\begin{array}{l}\text { Number } \\
\text { of patients }\end{array}$ & $\begin{array}{l}\text { Reinter- } \\
\text { ventions }\end{array}$ & $\begin{array}{l}\text { Rereinter- } \\
\text { ventions }\end{array}$ & $\begin{array}{c}\text { Total } \\
\text { repeated HM } \\
\text { by groups }\end{array}$ \\
\hline $4 b$ & 13 & $2(15.4 \%)$ & 0 & \multirow[b]{2}{*}{$4(20 \%)$} \\
\hline $5 \mathrm{a}$ & 7 & $1(14.3 \%)$ & $1(14.3 \%)$ & \\
\hline $5 b$ & 24 & $3(12.5 \%)$ & 0 & $10(10.8 \%)$ \\
\hline
\end{tabular}

According to the need for re-intervention (repeating the hysteroscopic metroplasty and resecting the residual septa) and types of CUA, the need to re-intervene was greater in the groups with types $4 \mathrm{~b}$ and $5 \mathrm{a}(4 / 20-20 \%)$ compared to the need for re-intervention of types $5 \mathrm{~b}$ and 6 (10/93-10.8\%). This was to be expected since such types of uterine malformations have a bigger septum or indentation of the uterine fundus, requiring more careful resection while taking care not to perforate the uterus.

In the two-year period following hysteroscopic metroplasty, there were 31 pregnancies in the group of patients with recurrent pregnancy loss and secondary infertility, which comprised 55 patients. Analysis of the reproductive outcome in those patients (before and after hysteroscopic metroplasty) showed a statistically significant decrease $(\mathrm{p}<0.05)$ of the abortion rate from $88.5 \%$ to $19.3 \%$, as well as an increase in the term delivery rate from $2.3 \%$ to $71 \%$. A significant decrease was noted in the preterm delivery group, and no ectopic pregnancy after the hysteroscopic metroplasty.

Table 5

Reproductive outcome before and after metroplasty

\begin{tabular}{|c|c|c|c|c|c|c|}
\hline $\begin{array}{c}\text { Secondary } \\
\text { infertility and } \\
\text { RPL group } \\
(55 \text { patients })\end{array}$ & $\begin{array}{c}\text { No.of } \\
\text { pregnancies } \\
(\%)\end{array}$ & $\begin{array}{c}\text { No.of } \\
\text { abortions } \\
(\%)\end{array}$ & $\begin{array}{c}\text { Fetal loss } \\
\text { after 22 gw } \\
(\%)\end{array}$ & $\begin{array}{c}\text { Ectopic } \\
\text { pregnancy } \\
(\%)\end{array}$ & $\begin{array}{c}\text { Preterm } \\
\text { delivery } \\
(\%)\end{array}$ & $\begin{array}{c}\text { Term } \\
\text { delivery } \\
(\%)\end{array}$ \\
\hline Before HM & $87(100 \%)$ & $77(88.5 \%)$ & $3(3.5 \%)$ & $4(4.6 \%)$ & $1(1.1 \%)$ & $2(2.3 \%)$ \\
\hline After HM & $31(56.4 \%)$ & $6(19.3 \%)$ & $0(0 \%)$ & $0(0 \%)$ & $3(9.7 \%)$ & $22(71 \%)$ \\
\hline$*$ S/NS & $/$ & $\mathrm{S}$ & $\mathrm{S}$ & $\mathrm{S}$ & $\mathrm{S}$ & $\mathrm{S}$ \\
\hline
\end{tabular}

* $\mathrm{S}$ - significant $(\mathrm{p}<0.05), \mathrm{NS}-$ non-significant

\section{Discussion}

Patients with congenital uterine malformations are the most significant group for treatment and improvement of reproductive outcome. They include CUA that are hysteroscopically correctible, and the types are: $4 \mathrm{~b}$ (partial bicornuate), 5a (complete septate), 5b (partial septate) and 6 (arcuate uterus). Systematic analysis of the obtained data showed a significant improvement in their reproductive outcome before and after hysteroscopic metroplasty.
One of the first published trials made on this topic by Acien in 1993 [28] compared the reproductive outcome in 173 patients with untreated uterine malformation who had 383 pregnancies, and a second group of 28 patients with normal uterus and 47 pregnancies. The abortion rate in patients with uterine malformations was $36 \%$, and the preterm delivery rate was $18 \%$, which was significantly higher $(p<0.01)$ than the rate of abortions of $8 \%$ and preterm delivery rate of $6 \%$ in patients with normal uterus. 
The term delivery rate in patients with uterine malformations was $44 \%$ and the live birth rate of $53 \%$, which was statistically significant $(\mathrm{p}<$ 0.001 ) and lower than the group with normal uterus where term delivery rate was $85 \%$ and live birth rate $89 \%$.

In the systematic review by Grimbizis in 2001 [12], where he analyzed the results from previous studies by Raga, Buttram and Heinonen $[4,29,30]$, in 102 patients with untreated arcuate uterus and the number of 241 pregnancies, the abortion rate was $25.8 \%$ and prematurity rate was $7.5 \%$. The rates for term delivery and live birth were $62.7 \%$ and $66 \%$, respectively.

A large number of studies have analysed the reproductive outcome in patients where congenital uterine anomalies were treated by hysteroscopic metroplasty, and they usually divide the patients into three groups: patients with recurrent pregnancy loss, patients with secondary infertility and previous pregnancy loss, and patients with primary infertility. The first and the second groups are treated with hysteroscopic metroplasty as a treatment for their previous poor reproductive outcome.

After performing hysteroscopic metroplasty, a significant decrease in rates of abortions and preterm delivery has been reported in treated patients. In the analysis by Grimbizis in 2001 , in patients who were pregnant after HM, the abortion rate was decreased to $16.4 \%$, while the preterm delivery rate was only $6.4 \%$, much lower than the previously-mentioned rates in untreated septate uterus $(44.3 \%$ and $22.4 \%$, respectively). On the contrary, a significant rise of term deliveries and live births was reported $(76.3 \%$ and $83.2 \%)$, in comparison with the rates before the HM that were lower $(33 \%$ and $50.1 \%$, respectively) [12].

In one of the recently-published studies by Sendag in 2010 [31] who analyzed 30 patients with different degrees of septate uterus, patients had a total of 74 pregnancies before metroplasty. Of these, ten (14\%) were carried to term, six $(8 \%)$ ended in preterm delivery, and $58(78 \%)$ ended in spontaneous abortion. At least one year after hysteroscopic metroplasty, a total of 20 pregnancies occurred. Of these, $11(55 \%)$ were carried to term, two $(10 \%)$ ended in preterm delivery, and seven $(35 \%)$ ended in spontaneous abortion.
In a study by Nouri in 2010 [32], the reproductive outcome was evaluated after hysteroscopic septoplasty in 64 women with septate uterus and primary or secondary infertility. A complete follow-up was available for $49 / 64$ (76\%) patients, and the overall pregnancy rate after hysteroscopic septoplasty was 69\% (34/49). The overall live birth rate (LBR) was $49 \%$ (24/49).

In a previous study by Saygili in 2002 [33] the reproductive outcome was analysed in 361 patients with septate uterus and hysteroscopic metroplasty who were followed for 18 months after the surgical intervention. The overall pregnancy rate was $49.8 \%$, and during the 18 month follow-up period $58 \%$ of them were term deliveries, and $18.8 \%$ preterm deliveries. In the group with previous spontaneous abortions a huge decrease in the abortion rate was noted, from $91.4 \%$ to $10.4 \%$. In the primary infertility group the pregnancy rate was up to $27.6 \%$. Research done by Fedele et al. in 2006, who were monitoring the reproductive outcome before and after HM, observed a decrease in the abortion rate from $80-90 \%$ to $20 \%$, while the term delivery rate rose from $5 \%$ to $80 \%$ [34].

In the recently published literature, in 2011 Roy [35] analysed 170 cases with HM over a period of 8.5 years where a significant decrease of unsuccessful pregnancies rate was noted, from $91.5 \%$ before metroplasty to $12.5 \%$ after metroplasty, and an increase in term delivery rate from $2.5 \%$ to $79.5 \%$. In the primary infertility group, the pregnancy rate increased to $56.5 \%$.

The analysis of our material also showed a significant improvement in the reproductive outcome, which was in agreement with publicshed medical literature. The comparison of the results before and after HM revealed a signifycant decrease of abortion rate from $88.5 \%$ to $19.3 \%$, which was comparable with the analysis of Roy, Fedele and Saygili [33-35]. In the analyzed two-year period there was even a more significant improvement in the reproductive outcome resulting with a term delivery rate that had increased from $2.3 \%$ to $71 \%$, which was also significantly increased in all the previously-mentioned studies (from 50-80\%) [12, 3335]. This is a confirmation of the fact that obtaining a normal uterine cavity in cases with congenital uterine malformations who have 
been hysteroscopically corrected, significantly influences not only the pregnancy rate, but also the capacity of the uterus for successful continuation of the pregnancy to term delivery.

\section{Conclusion}

In recent years, many published scientific papers concerning this topic have shown that congenital uterine anomalies represent an important factor for infertility and recurrent pregnancy loss. Even anomalies considered to be minor, such as an arcuate or partially septate uterus, have been detected as a cause of pregnancy loss, and after their surgical correction a significant improvement of the reproductive outcome in these patients has been reported.

We analysed the reproductive outcome before and after hysteroscopic metroplasty in our study group of patients diagnosed with infertility and recurrent pregnancy loss. A significant difference in the reproductive outcome has been noted, in decreased abortion rate and increased term delivery rates. Hysteroscopic metroplasty significantly improves the reproductive outcome in patients where surgically correctible congenital uterine anomaly exists. The knowledge of the importance of detection and correction of congenital uterine anomalies will give new opportunities for a better reproductive outcome for this group of patients.

\section{REFERENCE}

1. Chan YY, Jayaprakasan, K, Zamora J, et al. The prevalence of congenital uterine anomalies in unselected and high-risk populations: a systematic review. Hum Reprod Update. 2011 November; 17(6): 761-771.

2. Lin P, Bhatnagar K, Nettleton S, Nakajima S. Female genital anomalies affecting reproduction. Fertil Steril. 2002 Nov; 78(5): 899-915.

3. Propst AM, Hill JA 3rd. Anatomic factors associated with recurrent pregnancy loss. Semin Reprod Med. 2000; 18(4): 341-50. Review.

4. Raga F, Bauset C, Remohi J, Bonilla-Musoles F, Simon C, Pellicer A. Reproductive impact of congenital Mullerian anomalies. Hum Reprod. 1997; 12 (10): 2277-2281.

5. Speroff L, Glass RH, Kase NG. Development of the mullerian system. In: Mitchell C, eds. Clinical gynecologic endocrinology and infertility. 6th ed Baltimore, Md: Williams \& Wilkins, Lippincott, 1998; 124.

6. Harger JH, Archer DF, Marchese SG, et al. Etiology of recurrent pregnancy losses and outcome of subsequent pregnancies. Obstet Gynecol. 1983; 62: 574-581.

7. The American Fertility Society classifications of adnexal adhesions, distal tubal obstruction, tubal occlu- sion secondary to tubal ligation, tubal pregnancies, mullerian anomalies and intrauterine adhesions. Fertil Steril. 1988; 49: 944-55.

8. Saravelos SH, Cocksedge KA, Li TC. Prevalence and diagnosis of congenital uterine anomalies in women with reproductive failure: a critical appraisal. Hum Reprod Update. 2008 Sep-Oct; 14(5): 415-29.

9. Shokeir TA, Shalan HM, El-Shafei MM. Combined diagnostic approach of laparoscopy and hysteroscopy in the evaluation of female infertility: results of 612 patients. J Obstet Gynaecol Res. 2004 Feb; 30(1): 9-14.

10. Hourvitz A, Ledee N, Gervaise A, Fernandez H, Frydman R, Olivennes F. Should diagnostic hysteroscopy be a routine procedure during diagnostic laparoscopy in women with normal hysterosalpingography? Reprod Biomed Online. 2002 May-Jun; 4(3): 256-60.

11. Daly DC, Maier D, Soto-Albors C. Hysteroscopic metroplasty: six years experience. Obstet Gynecol. 1989; 73: 201-5.

12. Fedele L, Bianchi S. Hysteroscopic metroplasty for septate uterus. Obstet Gynecol Clin North Am. 1995; 22: 473-489.

13. Grimbizis G, Camus M, Tarlatzis BC, Bontis JN, Devroey P. Clinical implications of uterine malformations and hysteroscopic treatment results. Hum Reprod Update. 2001; 7(2): 161-74.

14. Grimbizis G, Camus M, Clasen K, Tournaye H, De Munck L, Devroey P. Hysteroscopic septum resection in patients with recurrent abortions or infertility. Hum Reprod. 1998; 13: 1188-1193.

15. Jacobsen LJ, De Cherney A. Results of conventional and hysteroscopic surgery. Hum Reprod. 1997; 12: 1376-1381.

16. Pellicer A. Shall we operate Mullerian defects? An introduction to the debate. Hum Reprod 1997; 12: 1371-1372.

17. Jones WH. Mullerian anomalies. Hum Reprod. 1998; 13: 789-791.

18. Homer HA, Li T, Cooke ID. The septate uterus: a review of management and reproductive outcome. Fertil Steril. 2000; 73: 1-14.

19. Wilcox AJ, Weinberg CR, O'Connor JF, et al: Incidence of early loss of pregnancy. $\mathrm{N}$ Engl J Med. 1988; 319: 189.

20. Mills JL, Simpson JL, Driscoll SG, et al: Incidence of spontaneous abortion among normal women and insulin-dependent diabetic women whose pregnancies were identified within 21 days of conception. $\mathrm{N}$ Engl J Med. 1988; 319: 1617.

21. Simpson JL, Mills JL, Holmes LB, et al: Low fetal loss rates after ultrasound-proved viability in early pregnancy. JAMA 1987; 258: 2555.

22. Wilson RD, Kendrick V, Wittmann BK, et al: Risk of spontaneous abortion in ultrasonically normal pregnancies. Lancet. 1984; 2: 920.

23. Gilmore DH, McNay MB: Spontaneous fetal loss rate in early pregnancy. Lancet. 1985; 1: 107.

24. Hoesli IM, Walter-Gobel I, Tercanli S, et al: Spontaneous fetal loss rates in a non-selected population. Am J Med Genet. 2001; 100: 106.

25. Ford HB, Schust DJ. Reccurent pregnancy loss: etiology, diagnosis and therapy. Rev Obstet Gynecol. 2009 Spring; 2(2): 76-83.

26. Regan L: A prospective study on spontaneous abortion. In Beard RW, Sharp F (eds): Early Pregnancy 
Loss: Mechanisms and Treatment, London, Springer-Verlag. 1988, p 22.

27. Knudsen UB, Hansen V, Juul S, Secher NJ. Prognosis of a new pregnancy following previous spontaneous abortions. Eur J Obstet Gynecol Reprod Biol. 1991; 39: 31-36.

28. Acien P. Reproductive performance of women with uterine malformations. Hum Reprod. 1993; 8: 122-126.

29. Buttram CV. Mullerian anomalies and their management. Fertil Steril. 1983; 40: 159-163.

30. Heinonen KP, Saarikoski S, Postynen P. Reproductive performance of women with uterine anomalies. Acta Obstet Gynecol Scand. 1982; 61: 157-162.

31. Sendag F, Mermer T, Yucebilgin S, et al. Reproductive outcomes after hysteroscopic metroplasty for uterine septum. Clin Exp Obstet Gynecol. 2010; 37(4): 287-9.

Р е 3 и м е

\section{ВЛИЈАНИЕТО НА ИСТЕРОСКОПСКАТА МЕТРОПЛАСТИКА ВРЗ РЕПРОДУКТИВНИОТ ИСХОД КАЈ ПАЦИЕНТКИ СО ИНФЕРТИЛИТЕТ И РЕКУРЕНТНА ФЕТАЛНА ЗАГУБА}

\section{Глигор Тофоски, Весна Антовска}

ЈЗУ Универзитетска клиника за гинекологија и акушерство, Медицински факултет, Универзитет „Св. Кирил и Методиј“, Скопје, Р. Македонија

Вовед: Пациентките со вродени утерини малформации (ВУМ) имаат намален репродуктивен потенцијал и понеповолен репродуктивен исход споредено со популацијата со нормална утерина празнина. Пациентките со нетретирани ВУМ имаат поголема стапка на абортуси, поголема стапка на фетална загуба и намалена стапка на живороденост. Хистероскопската метропластика е стандарден, безбеден и најминимално инвазивен метод за третман на коректибилни типови ВУМ.

Цел на студијата е да се анализира репродуктивниот исход кај одделни групи пациентки со ВУМ и инфертилитет, пред и по хистероскопска метропластика.
32. Nouri K, Ott J, Huber JC, Fischer EM, et al. Reproductive outcome after hysteroscopic septoplasty in patients with septate uterus - a retrospective cohort study and systematic review of the literature Reprod Biol Endocrinol. 2010; 8: 52.

33. Saygili E, Yildiz S, Erman-AkarM, et al. Reproductive outcome of septate uterus after hysteroscopic metroplasty. Arch Gynecolog Obstet. 2003; 268: 289-292.

34. Fedele L, Bianchi S, Frontino G. Septums and synechiae:approaches to surgical correction. Clin Obstet Gynecol. 2006; 49: 767-788.

35. Roy KK, Singla S, Baruah J, et al. Reproductive outcome following hysteroscopic septal resection in patients with infertility and recurrent abortions. Arch Gynecol Obstet. 2011; 283: 273-279.

Материјал и методи: Анализирани се 115 пациентки кај кои се изведени 129 интервенции хистероскопска метропластика на Универзитетската клиника за гинекологија и акушерство во Скопје, во едногодишен период од 1 јануари 2011 до 31 декември 2011 година. Пациентките и нивниот репродуктивен исход се следени во тек на двегодишен период и тие служеа како контролна група, имајќи ја предвид нивната претходна репродуктивна историja. Статистичката анализа е направена со употреба на Х2 тест и вредноста $\mathrm{p}<0,05$ се определи за статистички сигнификантна.

Резултати: Најчести детектирани ВУМ беа типовите $5 б$ и 6 , присутни со $83,3 \%$. Во тек на двегодишното следење кај 55 пациентки со претходна фетална загуба, по направената хистероскопска метропластика $\ddagger$ имаше 31 бременост. Има статистички значајно намалување на стапката на абортуси од $88,5 \%$ на $19,3 \%$, како и зголемување на стапката на термински породувања од 2,3\% на $71 \%$.

Заклучок: Хистероскопската метропластика значително го подобрува репродуктивниот исход кај пациентките со претходна фетална загуба.

Клучни зборови: хистероскопија, репродукција, инфертилитет, бременост. 